CATALAN REVIEW

Catalan Review

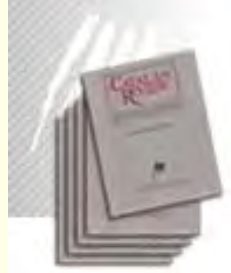

You are accessing the Digital Archive of the Catalan Review Journal.

By accessing and/or using this Digital Archive, you accept and agree to abide by the Terms and Conditions of Use available at http://www.nacs-

catalanstudies.org/catalan_review.html

Catalan Review is the premier international scholarly journal devoted to all aspects of Catalan culture. By Catalan culture is understood all manifestations of intellectual and artistic life produced in the Catalan language or in the geographical areas where Catalan is spoken. Catalan Review has been in publication since 1986 .
NORTH

AMERICAN

CATALAN

SOCIETY
Esteu accedint a l'Arxiu Digital del Catalan Review

A l' accedir i / o utilitzar aquest Arxiu Digital, vostè accepta i es compromet a complir els termes i condicions d'ús disponibles a http://www.nacs-

catalanstudies.org/catalan_review.html

Catalan Review és la primera revista internacional dedicada a tots els aspectes de la cultura catalana. Per la cultura catalana s'entén totes les manifestacions de la vida intel lectual i artística produïda en llengua catalana o en les zones geogràfiques on es parla català. Catalan Review es publica des de 1986.

\title{
Montserrat Roig: The dialectics of castration Ramon Buckley
}

Catalan Review, Vol. VII, number 2 (1993), p. 129-136 


\section{MONTSERRAT ROIG: THE DIALECTICS \\ OF CASTRATION}

\section{RAMON BUCKLEY}

In the fall of I991 not only did we loose a friend but, above all, a human being who, it seems to me, was undergoing a most profound change in her character, her personality, even in her own beliefs... I still recall the mocking smile in her face as I was introducing her to the Madrid University students in 1988. The students were eager to know about "la Roig", the person who had so stirred the imagination of an earlier generation of students, those who fought the Franco police on campus in the last years of the previous regime... "Here is the woman" I rousingly said in my introductory speech "who described herself as a feminist first, a Catalanist second, and a Marxist third". I talked about her involvement in the campus riots of the late I960's, about the way her Catalan novels became instant best-sellers in Madrid, about the Catalan leadership in the "rebel» generation of 1968 which boasted the protest songs of Raimon, Serrat and Lluís Llach, the scandalous literature of Terenci Moix, the first stirrings of a truly feminist literature in the novels of Montserrat Roig... When I was done, she calmly took the floor to say, with a wistful smile, that "all that Ramon had said was very true but all that had happened a long time ago and that she was, by now, a very different person".

It took me a while to understand quite how "different" Montserrat had become. I must confess I had not followed her work in the early eighties very closely. I was aware she had devoted her attention to researching the fate of the Catalan nationalists who ended up in nazi concentration camps and that she had also spent time in Russia, researching the nazi siege of Leningrad. But I had not read L'Opera Quotidiana and La Veu Melodiosa, the other novel which was to mark her spiritual evolution, had not yet been published. I 
was therefore unaware of the magnitude of a change which only now, two years after her death, I can begin to fathom.

This change can best be seen in her attitude towards feminism. Roig's brand of feminism in the late sixties and early seventies was close to Julia Kristeva's. Kristeva also linked feminism with class struggle as she fought the establisment in the Paris riots of 1968. Women, like the proletariat, were involved in a power struggle with the bourgeoisie. The assumption was that, once political power was gained and all discrimination effectively ceased, feminism as such would disappear and gender frontiers and barriers would melt in exactly the same fashion as class distinctions in the wake of the triumph of the proletariat. "Kristeva" says Toril Moi in her Sexual/Textual Politics does not have a theory of feminity, much less a theory of femaleness... What she does have is a theory of marginality, subversion and dissidence... In so far as women are defined as "marginal" by patriarchy, their struggle can be theorized as any other struggle by a centralized power». Or as Kristeva herself puts it: "Call it woman or oppressed classes of society, it is the same struggle and never one without the otherm.'

To put it another way, Roig was writing novels for women readers, about women characters, for women's rights but not necessarily from the woman within her: "He escrito con mente de hombre y cuerpo de mujer" she says in ¿Tiempo de Mujer? "Sé que es el primer paso hacia la esquizofrenia pero todo novelista es un esquizofrénico en potencia... He tomado prestado el lenguaje de los hombres. $\eta^{2}$

Roig's plight (as well as Kristeva's) exemplifies the dilemma of feminism in the sixties. Women could only be understood if they were to be considered from the "outside", that is, from the male viewpont. The rights of women could only be asserted using the language of the male, the code of patriarchy, since women were involved in a power struggle and the same language was to be used

\footnotetext{
Toril Moi, Sexual/Textual Politics, N.Y. 1990, p, n12.

${ }^{2}$ Montserrat Roig, ¿Tiempo de Mujer?, Barcelona, I980, p. 47.
} 
if power was to be gained. Montserrat Roig's novels were powerful indictments indeed against male domination over women in Catalan history over the last one hundred years. Moreover, they present a dramatic picture of the downtrodden feminine condition through a vivid portrayal of female characters. But these characters are seen from "without" and not from "within", we see their condition but not their sensibility. For that, Roig needed to turn to her predecessor.

It would be impossible to underestimate the influence of Merce Rodoreda on Montserrat Roig. Rodoreda's books were bestsellers in the Barcelona of the nineteen sixties and receiving high critical acclaim. Yet if we study the early works of Roig (the three novels usually referred to as her "trilogy") it is virtually impossible to find any trace of Rodoreda, where the older writer advises her: "Live first and write later - a piece of advice Roig certainly followed! But, other than this vague admonition, there is no trace of Rodoreda on the early Roig.

It is possible to argue, using Bloomian terminology, that Rodoreda was the "precursor" of Montserrat Roig. She would then (following Bloom's schema in The Anxiety of Influence) go through a period of rejection of the precursor until the precursor was finally absorbed and accepted in her own terms. In an interview, Roig declared that she had to «kill" Rodoreda because she had found her "voice» and she needed to find her own.

It would, indeed, be hard to define Rodoreda's "voice» in simple terms. But perhaps its keynote would be close to what Bonnie Costello, speaking about the poetry of Marianne Moore, calls "humility": "Moore" says Costello "wants to create an interest which overt self-assertion would snuff out. Moore's humility and restraint are not passive defenses but ways of gathering force, as a bow is pulled back in order to carry the arrow farther when it is finally released". In language, says Moore herself, humility is an indispensable teacher, ennabling concentration to heighten gustom. Geoffrey Hartman points out the "sselffless assertion of self" in the poetry of Moore and goes on to suggest that wthe armor she des- 
cribes is the modesty whereby the self is made strong to resist itself, but also strong to assert itself against voracious dogmatism". ${ }^{3}$

Costello's and Hartmann's definition of "humility" in Moore englightened me on the writing of Mercè Rodoreda. For humility is not a "weakness" in her style but precisely her maximum source of strength. It is the humble Colometa in Plaça del Diamant who will outlive and outpower the men in her life but, more precisely, it is the humility of vision of Rodoreda, her concentration on everyday objects and experiences, the underprivileged or "low" viewpoint from which she narrates, which is the very essence of the strength of her prose.

Now we know what it was that Montserrat Roig unconsciously rejected in Rodoreda, her shumility", apparently so weak but really so strong. If there was one thing Montserrat Roig was not (or, for that matter, any one of us) was whumblem. We were, in the late sixties and early seventies, loud and assertive. Rodoreda could hardly be the model that Roig would seek as unavoidable reference point of any woman writing in Catalunya in the nineteen sixties... This schizofrenia, this unavoidable contradiction, would only be resolved in Montserrat Roig's later novels.

In the two novels Montserrat Roig wrote in the eighties (L'Òpera Quotidiana and La Veu Melodiosa) there is an inversion of her stance as a novelist. If before she was writing about women "yet using the words of the malen (as she herself admits), now she will write about the male, yet very clearly from a feminine perspective. Thus she will move very closely to Rodoreda's own stance, writing often in first person feminine, like Rodoreda does in La Plaça del Diamant.

Horaci Duc is the protagonist in L'Opera Quotidiana. Duc is in his fifties, a butcher by trade, a catalanista and a confirmed bachelor. He is a lonely person whose two encounters with love end up in tragedy. Duc tries to play Pigmalion with lower class servant girls

${ }^{3}$ Sally McConnell, Women and Language in Literature and Society, N.Y., 1980, p. 223. 
coming to Barcelona from the south and is finally outwitted by his own disciples. Montserrat Roig views the world she knows best, the Barcelona of the petite bourgeoisie, as an opera stage where everyone "sings" to everyone else the drama or melodrama of his or her own life. There is, however, a difference between the female "sopranos" and the male "tenors". The women sing their particular libreto with "guston, above all with feeling. They literally put their hearts out, thus achieving a spiritual katharsis, a release of emotions which releaves them of their plight.

Males, however, are incapable of such katharsis, of such liberation. Horaci Duc lets out his story but not his feelings, thus he is incapable of self-liberation and ultimately, of self-knowledge.

"Tots els homes som una mica infeliços."

"Per què ho diu?"

"Doncs per això, perquè mai no poden deixar-se anar, demostrar les seves febleses.n

"És llàstima que els homes no puguin explicar allò que els passa en el seu interior, allò que no té forma de drama, que no és qualificat de tragèdia aparent»."

Men, argues Roig, are emotionally castrated human beings, unable to express their feelings. This castration, in the case of Horaci Duc, occurs during the years following the Spanish civil war, the years in which Horaci Duc grew up as a young man in Barcelona. In the years following the war, Horaci was caught up in what can best be described as the "dialectics of castration". Franco's stringent measures against the use of the Catalan language ("ihablad la lengua del imperio!» written all over Barcelona) created, by reaction, a resistance of heroes and martyrs prepared to die for the cause of scatalanism". This was the case of Duc's friend Pagès, tortured and killed in the Franco prisons. Duc was forced, as much by Franco's oppression as by his friend Pagès' reaction to this opression, into taking up a role which does not befit him, a heroic role which, as he finds out too late for his own good, is totally alien to his personality. Thus the

${ }^{4}$ Montserrat Roig, L'Òpera Quotidiana, Barcelona, 1982, p. 117. 
young Horaci Duc is "castrated" not only by Franco's repressive measures, but by the very reaction of his catalanist friends, the long fight from the underground which they undertook against Franco's police. The binary opposition of "franquismo" and "catalanismo" combined to produce a deadly effect on his personality, nipping it at the bud, not allowing it to grow or to flourish.

"They made me believe" says Duc of his fellow catalanistas "that I was better than I really was, they broke down my adolescent dreams, they broke down my faith in life, they did not allow me to be what I really was, to exercise my faith in man, in myselfy.

Montserrat travelled a long way since the early novels of the first part of her career. Still placing the blame squarely on Franco's dictatorship, she now contemplates the forces that opposed the Franco regime (Marxism, Catalanism, even feminism) as potentially stiffling to the development of the human personality. Duc is caught in a deadlock of opposing ideologies, unable to free himself from the dialectics Franco and his opposition had established: to Franco, all oppositionists to his regime were labelled as "rojos"; to the "reds", everyone outside of the communist party was a fascist, "un facha".

Which is the way out of the "dialectics of castration"? How could a man hope to disentangle himself from this dialectical process? Only, says Roig in her final novel La Veu Melodiosa, if he was prepared to abandon not "this" or "that" ideology, but the very concep of ideology itself. Patriarchy, suggests Roig in her final novel, «is» ideology. Whether from the right or from the left, patriarchy will always try to impose itself by conceptualising reality. But is this necessary? Do we need to offer an intelectual framework to solve our everyday problems? Should we not approach reality from our emotions, freed from any preconceived ideas? And is this not matriarchy? If matriarchy is anything, is it not an emotional response to the world we live in?

Let us imagine, says Roig in her final novel, that a member of the male species escaped Franco's harsh repression of the post-civil

5 Montserrat Roig, L'Õpera Quotidiana, p. 132. (my own translation) 
war period. How could that be? In La Veu Melodiosa, Roig poses the question of the so-called "inner exiles", the persons who remained in Spain after the end of the war but who, in effect, closed themselves off from the system, leading isolated existences. L'Espardenya is educated by private tutors and confined to his home, in a well-to-do neighborhood of Barcelona. Since he is never exposed to the "virus" of the Franco system, he does not need an uantidote" to the virus of "franquismo", which was, of course, "marxismo". Instead of reading about the causes of poverty in terms of class struggle dialectics. L'Espardenya prefers to visit with the poor, to share their misery, to offer them a helping hand. "If there are people who don't have a home to live in" says Roig, ironically "don't worry, it's all explained in the books... if they die in the floods (refering to the Barcelona floods of 1962) don't worry, the books will tell you what happened... if people are out of work, the books will tell you why... it was certainly in bad taste to feel pity for the poor in those daysm. ${ }^{6}$

Roig is merciless about herself, about the way she was, about the way we were, about her Marxist days, about the time when everything was intellectualized, conceptualized, about that moment in history when everything was "thought" but nothing was "felt". L'Esperdenya was a victim both of the repressors and the repressed, of the fascist police as well as of the "enlightened" Marxist students who turn their backs on him... He is the hero of Montserrat Roig's final novel. Only thtough his "melodious voice" will the screams of the two opposing camps (fascists and Marxists) be finally reconciled.

To put this in terms of gender, the patriarchic machismo of the Franco regime was questioned by its opposite, the radical feminism of the sixties and early seventies. The "melodious voice" which Montserrat Roig mentions in her final novel will necessarily be androginous, spoken by a man, yet containing much of the female rhetoric. Roig has departed from Kristeva and is now closer to Cixous' concept of a "decipherable femininity, which can be read in lation)

${ }^{6}$ Montserrat Roig, L'a Veu Melodiosa, Barcelona, 1987, p. Ir4. (my own trans- 
writing produced by male or femalem. Cixous' concept of «jouissancew is in Roig more emotional than physical, more a liberation of the spirit than of the body.?

By creating one of the first truly androginous characters in modern Catalan literature, Roig took her writing beyond her early work to create one of the truly postmodern texts in Spanish literature. By stressing the importance of emotion, of feeling, she re-established the link between her own writing and that of her precursor, Mercè Rodoreda. She died at the threshold of a new personal awakening, of a new beginning in the continuous tradition of Catalan women writing. She died, I believe, at the verge of discovering her own voice as a novelist, beyond the dialectics of castration, which had so influenced her own early writing.

RAMON BUCKLEY

SITGES

7 Hélène Cixous, Le Rire de la Meduse, Paris, 1975. 